Bangl. J. Vet. Med. (2010). 8(1): 5 - 10

\title{
ISOLATION AND IDENTIFICATION OF MICROFLORA FROM APPARENTLY HEALTHY CAGED PARROTS OF DHAKA ZOO OF BANGLADESH
}

\author{
J. Akhter ${ }^{1}$, M. T. Hossain ${ }^{1 *}$, M. T. Islam ${ }^{2}$, M. P. Siddique ${ }^{1}$ and M. A. Islam ${ }^{1}$ \\ Department of Microbiology and Hygiene ${ }^{1}$, Department of Medicine ${ }^{2}$, Faculty of Veterinary Science, \\ Bangladesh Agricultural University, Mymensingh -2202, Bangladesh
}

\begin{abstract}
The research work was conducted to isolate and identify the microflora from apparently healthy caged parrots. A total of 45 samples (oral swabs, cloacal swabs and feces) were collected from five types of caged parrots (Gray cockatiels, Rose ringed parakeet, Alexandriane parakeet, Red breast parakeet and Blossom headed parakeet) of Dhaka Zoo during the period from April to August 2009. The samples were cultured on different bacteriological media and the bacteria were identified by their cultural and biochemical properties. All the isolates were allowed for antibiogram study. The bacteria isolated in this study from different types of caged parrots were E. coli (64.44\%), Salmonella spp. (46.67\%), Staphylococcus spp. (46.67\%), Pasteurella spp. (33.33\%), Proteus spp. (6.67\%) and some unidentified Gram-positive and Gram-negative bacteria. Of these isolates, E. coli was the most frequent isolate. The frequency of Gram-negative bacteria was higher in this study. The percentage of bacterial isolates recovered from each type of parrots was almost similar. Irrespective of types of parrots, the higher percentage of different bacteria was isolated from cloacal swab $(77.78 \%)$ followed by feces $(75.56 \%)$. The $68.89 \%$ isolates were recovered from oral swab. All the suspected isolates of Salmonella spp. were confirmed by slide agglutination test using Salmonella polyvalent 'O' antiserum. Among the 21 Salmonella spp. isolated in this study, 4 (19.05\%) isolates were identified as $S$. Pullorum when tested with specific antisera against $S$. Pullorum. The results of antibiotic sensitivity tests revealed that ampicillin and amoxicillin were completely resistant to E. coli and Pasteurella spp.; ampicillin to Proteus spp.; and furazolidone to Salmonella spp. and Pasteurella spp. However, the antibiotics of fluoroquinolone group such as ciprofloxacin, norfloxacin and enrofloxacin showed moderate to high sensitivity against almost all the bacterial isolates. Of these, ciprofloxacin was found to be consistently highly sensitive to all the bacterial isolates.
\end{abstract}

Key words : Isolation, identification, microflora, caged parrot

\section{INTRODUCTION}

Parrots are found all over the world from a long time. They are popular as pets due to their sociable and affectionate nature, intelligence, bright colors, and ability to imitate with human voices. Economically they can be beneficial to communities as sources of income from the pet trade. The domesticated Budgerigar, a small parrot, is the most popular of all pet bird species. Pet birds are the source of recreation for human especially children. Pet parrots are kept in a cage or aviary; though generally, tame parrots should be allowed to be taken out regularly. Species of parrot vary in their temperament, noise level, talking ability, cuddliness with people. Parrots are excellent companion animals, and can form close, affectionate bonds with their owners. However they invariably require an enormous amount of attention, care and intellectual stimulation to thrive (http://www.parrotsanctuary.co.uk). Depending on locality, parrots may be either wild caught or be captive bred, though in most areas without native parrots, pet parrots are captive bred. Among a larger number of species of parrots, Alexandrine Parakeet, Cockatiel, Rose-ringed Parakeet, Red breast parakeet, Blossom Headed parakeet, Common Hill Myna, Macaw, Lovebird etc species are available in Bangladesh and widely reared in cage particularly in Dhaka Zoo as ornamental birds.

Parrots are often suffered from many bacterial diseases with often involvement of normal flora or environmental pathogens in response to stress and immunosuppression. Bacterial enteritis is often a spontaneous stress associated disease caused mainly by E. coli, Klebsiella, Salmonella, Pasteurella, Pseudomonas, Aeromonas and Citrobacter (Altman and Robert, 1997). Most of the enteric Salmonellae (Salmonella typhimurium, Salmonella enteritidis) are motile and classified as paratyphoid organisms and the diseases they produce are termed paratyphoid infections (Kirk et al., 2002). As with bacterial enteritis, bacterial respiratory disease is also often a stress associated phenomenon where Klebsiella, Escherichia coli, Enterobacter, Pseudomonas, Pasteurella and Mycoplasma are commonly involved (Friend and Franson, 1999).

*Corresponding author's e-mail: tofazzalmh@yahoo.com

Copyright (C) 2010 Bangladesh Society for Veterinary Medicine

All rights reserved 1729-7893/0193/10 


\section{J. Akhter and others}

Many zoonotic diseases are transferred from cage or pet birds to human through direct or indirect contact of the diseased or carrier birds. Visitors are more susceptible to acquire zoonotic diseases from cage birds in zoo. Bacteria are one of the most common causes of zoonotic diseases. For this, proper isolation, identification and characterization of the bacteria are essential to control zoonotic diseases. Outbreaks of zoonoses have been traced to human interaction with and exposure to animals at fairs, petting zoos, and in other settings. In 2005, the Center for Disease Control and Prevention (CDC) issued an updated list of recommendations for preventing zoonoses transmission in public settings. The CDC recommendations, which were developed in conjunction with the National Association of State Public Health Veterinarians, include sections on the educational responsibilities of venue operators, managing public and animal contact, and animal care and management (CDC, 2005). In 2002, seven people became ill with E. coli: 0157117 infections after visiting a large agricultural fair in Ontario, Canada. Investigators of outbreak conducted a case-control study, which indicated that goats and sheep from a petting zoo were the source of the E. coli among fair visitors. Other indications were that the fencing and environment surrounding the petting zoo that could have been a source of transmission (Warshawsky, 2002).

Very few works have been studied on the isolation and identification of bacteria from caged birds in Bangladesh and the present study, therefore, was undertaken to isolate and identify important species of bacteria from apparently healthy caged parrots, and to determine antibiotic sensitivity pattern of the isolated bacteria.

\section{MATERIALS AND METHODS}

A total of 45 cloacal swab, feces and oral swab samples, 15 of each, were carefully collected from five types (Gray cockatiel, Rose ringed parakeet, Alexandriane parakeet, Red breast parakeet and Blossom headed parakeet) of apparently healthy caged parrots of Dhaka Zoo, Mirpur, Dhaka. Immediately after collection, each sample was inoculated into sterile nutrient both (NB) and kept in ice box and transported to the Bacteriology Laboratory of the Department of Microbiology and Hygiene, Bangladesh Agricultural University, Mymensingh. The inoculated nutrient broths were incubated at $37^{\circ} \mathrm{C}$ for $24 \mathrm{hrs}$ and then streaked onto different bacteriological media such as NA, EMB, MC, SS, BGA, BA, TSI (Himedia, India) to obtain pure culture of the bacteria. Gram's staining was performed to study the morphology of bacterial isolates (Merchant and Packer, 1967) and motility test was performed to differentiate motile bacteria from non-motile one (Cowan, 1985). Leishmann's staining was performed to identify bipolar organisms such as Pasteurella multocida according to the procedures described by Buxton and Fraser (1977). Isolated bacteria from each sample was biochemically identified by sugar fermentation test, indole test, MR-VP test, catalase and coagulase tests as per methods described by Cheesbrough (1984). Besides, triple sugar iron agar (TSI agar) slant was used to identify the lactose, saccharose and dextrose fermenters. The medium also helped to determine the ability of the organisms to produce hydrogen sulphide. The test organisms were heavily seeded with a platinum loop over the surface of the slants and stabbed into the butt of the TSI agar (Himedia, India). After incubation at $37^{\circ} \mathrm{C}$ for 24 hours, the tubes were examined for any change in the slant or butt (Cheesbrough, 1984).

\section{Hemolytic activity}

Hemolytic activities of the isolated bacteria were studied as per the method described by Chatterjee et al. (1990). All the isolates were tested for the production of hemolysis by growing them on bovine BA plate and were then incubated at $37^{\circ} \mathrm{C}$ for 24 hours. The colony developed on the BA plate was examined for various types of hemolysis. Hemolytic patterns of the bacteria were categorized according to the types of hemolytic zone they produced on BA plates and were listed as follows: (i) Alpha ( $\alpha$ ) hemolysis: a zone of greenish discoloration around the colony manifested by partial hemolysis and (ii) Beta ( $\beta$ ) hemolysis: complete clear zone of hemolysis around the colony.

\section{Sero-grouping of Salmonella}

Sero-grouping of Salmonella isolates was performed by slide agglutination test using polyvalent ' $\mathrm{O}$ ' as well as Salmonella Pullorum antisera. The test was performed according the protocol of Buxton and Fraser (1977). Briefly, an amount of $20 \mu \mathrm{l}$ of antisera was taken with the micropipette on a glass slide placed on dark background. A small amount of bacterial mass from a single colony was taken with a bacteriological loop and placed on slide and mixed properly. The slide was agitated gently for 5 to 10 seconds. The reaction was read by the naked eye holding the slide in front of a light source against a black background. Positive reaction was recorded by a visible agglutination. 
Isolation and identification of microflora from healthy parrots

\section{Antibiotic sensitivity test}

Antibiotic sensitivity test was done using disc diffusion test following the method described by Bauer et al. (1966). One milliliter of fresh broth culture was poured on nutrient agar media and spreaded uniformly. Antibiotic discs (Mast Group Ltd, Merseyside, UK) were placed apart onto the surface of the inoculated plates aseptically with the help of a sterile forceps and incubated at $37^{\circ} \mathrm{C}$ for 24 hours. After incubation, the plates were examined and the diameters of the zone of inhibition were measured. Individual antibiotic was recorded as highly sensitive, moderately sensitive, less sensitive or resistant depending on the area of inhibition of bacterial growth as per the method described by Bauer et al. (1966).

\section{RESULTS AND DISCUSSION}

The bacteria isolated in this study were E. coli, Salmonella spp., Pasteurella spp., Staphylococcus spp., Proteus spp. and some other unidentified Gram-positive and Gram-negative bacteria. This finding is in consistent with the findings of Sandra et al. (1998) and Doneley (2009). In addition to these organisms, they also isolated Streptococcus spp., Klebsiella pneumoniae, Pseudomonas spp., Corynebacterium spp., Lactobacillus spp. etc. The specific media and biochemical tests were used for the identification of the bacterial isolates which was previously suggested by a number of authors (Buxton and Fraser, 1977 and Freeman, 1985). The cultural and biochemical properties revealed by the isolates in this study are in agreement with the reports of Buxton and Fraser (1977) and Cheesbrough (1984).

Among 45 different types of samples collected from parrots, a total of $29(64.44 \%)$ samples were found positive for E. coli, of which $6(40 \%)$ were isolated from oral swabs, $12(80 \%)$ from cloacal swabs and 11 $(73.33 \%)$ from feces of different types of parrots; 21 (46.67\%) samples were found positive for Salmonella spp., of which $5(33.33 \%)$ were isolated from oral swabs, 9 (60\%) from cloacal swabs and 7 (46.67\%) from feces; 21 (46.67\%) samples were found positive for Staphylococcus spp., of which $8(53.33 \%)$ were isolated from oral swabs, 7 (46.67\%) from cloacal swabs and 6 (40\%) from feces; $15(33.33 \%)$ samples were found positive for Pasteurella spp., of which 6 (40\%) were isolated from oral swabs, 4 (26.67\%) from cloacal swabs and 5 (33.33\%) from feces; 3 (20\%) samples were found positive for Proteus spp., which were isolated from oral swabs only (Table 1). The bacteria most frequently isolated from all types of caged parrots was E. coli (64.44\%) followed by Salmonella spp. (46.67\%), Staphylococcus spp. (46.67\%), Proteus spp. (6.67\%) and Pasteurella spp. (33.33\%). Bowman and Jacobson (1980) and Bangert et al. (1988) also reported that E. coli was the most frequent isolate from clinically healthy psittacine birds.

Table 1. Overall percentages of different types of bacteria isolated from different types of samples collected from caged parrots

\begin{tabular}{|c|c|c|c|c|}
\hline \multirow[t]{2}{*}{ Name of bacteria } & \multicolumn{4}{|c|}{ Number of each type of samples } \\
\hline & $\begin{array}{l}\text { Oral swab } \\
(\mathrm{n}=15)\end{array}$ & $\begin{array}{l}\text { Cloacal swab } \\
(\mathrm{n}=15)\end{array}$ & $\begin{array}{l}\text { Feces } \\
(\mathrm{n}=15)\end{array}$ & Total \\
\hline E. coli & $6(40 \%)$ & $12(80 \%)$ & $11(73.33 \%)$ & $29(64.44 \%)$ \\
\hline Salmonella spp. & $5(33.33 \%)$ & $9(60 \%)$ & $7(46.67 \%)$ & $21(46.67 \%)$ \\
\hline Pasteurella spp. & $6(40 \%)$ & $4(26.67 \%)$ & $5(33.33 \%)$ & $15(33.33 \%)$ \\
\hline Staphylococcus spp. & $8(53.33 \%)$ & $7(46.67 \%)$ & $6(40 \%)$ & $21(46.67 \%)$ \\
\hline Proteus spp. & $3(20 \%)$ & $0(0 \%)$ & $0(0 \%)$ & $3(6.67 \%)$ \\
\hline $\begin{array}{l}\text { Unidentified Gram positive } \\
\text { Rod }\end{array}$ & $1(6.67 \%)$ & $1(6.67 \%)$ & $1(6.67 \%)$ & $3(6.67 \%)$ \\
\hline $\begin{array}{l}\text { Unidentified Gram negative } \\
\text { Rod }\end{array}$ & $1(6.67 \%)$ & $1(6.67 \%)$ & $1(6.67 \%)$ & $3(6.67 \%)$ \\
\hline $\begin{array}{l}\text { Unidentified Gram negative } \\
\text { coccobacilli }\end{array}$ & $1(6.67 \%)$ & $1(6.67 \%)$ & $3(20 \%)$ & $5(13.33 \%)$ \\
\hline Total & $31(68.89 \%)$ & $35(77.78 \%)$ & $34(75.56 \%)$ & \\
\hline
\end{tabular}

$\mathrm{n}=$ Number of examined samples. 


\section{J. Akhter and others}

It is interesting to note that only 24 isolates were Gram-positive among 100 isolates. This finding differ from earlier observation of Bangert et al. (1988) and Flammer and Drewes (1988) who reported higher incidence of Gram-positive bacteria in various species of psittacine birds. This variation could not be explained exactly, however, it may be due to differences in the site of sampling and sample size. All the suspected Salmonella were identified by using Salmonella polyvalent ' $\mathrm{O}$ ' antiserum. Of the 21 Salmonella spp. isolated in this study, 4 $(19.05 \%)$ isolates were identified as Salmonella Pullorum when tested with specific antisera against Salmonella Pullorum. The occurrence of Salmonella Pullorum in psittacine birds is not common (Fowler, 1986; Allgayer et al., 2008). However, the present finding is in agreement with the findings of Shimakura et al. (1985) and Deem et al. (2005) who also reported the occurrence of Salmonalla Pullorum in psittacine birds.

Irrespective of type of samples, $6(66.6 \%)$ samples from each type of parrots were positive for E. coli except Red breast parakeet from which $5(55.56 \%)$ samples were found positive; $5(55.56 \%)$ samples each from Rose ringed parakeet and Red breast parakeet; 4 (44.44\%) samples each from Gray cockatiel and Blossom headed parakeet, and $3(33.33 \%)$ samples from Alexandriane parakeet were found positive for Salmonella spp.; 3 (33.33\%) samples each from Rose ringed parakeet and Red breast parakeet, 4 (44.44\%) from Alexandriane parakeet, $5(55.56 \%)$ from Blossom headed parakeet, and 6 (66.67\%) from Gray cockatiel were found positive for Staphylococcus spp.; 2 (22.22\%) samples each from Gray cockatiel and Rose ringed parakeet, $4(44.44 \%)$ samples each from Red breast parakeet and Blossom headed parakeet, and 3 (33.33\%) samples from Alexandriane parakeet were found positive for Pasteurella spp.; 1 (11.11\%) sample each from Gray cockatiel, Alexandriane parakeet and Red breast parakeet was found positive for Proteus spp. Samples from Rose ringed parakeet and Blossom headed parakeet were found negative for Proteus spp. (Table 2). Among the five types of parrots, no remarkable variation was found in the percentage of bacterial isolates. Almost similar number of isolates of different bacteria was recovered from each type of parrots.

Table 2. Overall percentages of different types of bacteria isolated from each type of parrots

\begin{tabular}{|c|c|c|c|c|c|}
\hline \multirow[b]{2}{*}{ Name of bacteria } & \multicolumn{5}{|c|}{ Number of different types of bacteria isolated from each type of parrots $(n=9)$} \\
\hline & $\begin{array}{l}\text { Gray } \\
\text { cockatiel }\end{array}$ & $\begin{array}{l}\text { Rose ringed } \\
\text { parakeet }\end{array}$ & $\begin{array}{l}\text { Alexandriane } \\
\text { parakeet }\end{array}$ & $\begin{array}{l}\text { Red breast } \\
\text { parakeet }\end{array}$ & $\begin{array}{l}\text { Blossom headed } \\
\text { parakeet }\end{array}$ \\
\hline E. coli & $\begin{array}{l}6 \\
(66.67 \%)\end{array}$ & $6(66.67 \%)$ & $\begin{array}{l}6 \\
(66.67 \%)\end{array}$ & $\begin{array}{l}5 \\
(55.56 \%)\end{array}$ & $\begin{array}{l}6 \\
(66.67 \%)\end{array}$ \\
\hline Salmonella spp. & 4 & $\begin{array}{l}5 \\
(55.56 \%)\end{array}$ & $\begin{array}{l}3 \\
(33.33 \%)\end{array}$ & $\begin{array}{l}5 \\
(55.56 \%)\end{array}$ & $\begin{array}{l}4 \\
(44.44 \%)\end{array}$ \\
\hline Pasteurella spp. & $\begin{array}{l}2 \\
(22.22 \%)\end{array}$ & $\begin{array}{l}2 \\
(22.22 \%)\end{array}$ & $\begin{array}{l}3 \\
(33.33 \%)\end{array}$ & 4 & 4 \\
\hline Staphylococcus spp. & $\begin{array}{l}6 \\
(66.67 \%)\end{array}$ & $\begin{array}{l}3 \\
(33.33 \%)\end{array}$ & $\begin{array}{l}4 \\
(44.44 \%)\end{array}$ & $\begin{array}{l}3 \\
(33.33 \%)\end{array}$ & $\begin{array}{l}5 \\
(55.56 \%)\end{array}$ \\
\hline Proteus spp. & 1 & $\begin{array}{l}0 \\
(0 \%)\end{array}$ & $\begin{array}{l}1 \\
(11.11 \%)\end{array}$ & $\begin{array}{l}1 \\
(11.11 \%)\end{array}$ & $\begin{array}{l}0 \\
(0 \%)\end{array}$ \\
\hline $\begin{array}{l}\text { Unidentified Gram } \\
\text { positive Rod }\end{array}$ & $\begin{array}{l}1 \\
(11.11 \%)\end{array}$ & $\begin{array}{l}2 \\
(22.22 \%)\end{array}$ & $\begin{array}{l}0 \\
(0 \%)\end{array}$ & $\begin{array}{l}0 \\
(0 \%)\end{array}$ & $\begin{array}{l}0 \\
(0 \%)\end{array}$ \\
\hline $\begin{array}{l}\text { Unidentified Gram } \\
\text { negative Rod }\end{array}$ & $\begin{array}{l}0 \\
(0 \%)\end{array}$ & $\begin{array}{l}0 \\
(0 \%)\end{array}$ & $\begin{array}{l}1 \\
(11.11 \%)\end{array}$ & $\begin{array}{l}1 \\
(11.11 \%)\end{array}$ & $\begin{array}{l}1 \\
(11.11 \%)\end{array}$ \\
\hline $\begin{array}{l}\text { Unidentified Gram } \\
\text { negative coccobacilli }\end{array}$ & 1 & $\begin{array}{l}1 \\
(11.11 \%)\end{array}$ & $\begin{array}{l}1 \\
(11.11 \%)\end{array}$ & $\begin{array}{l}2 \\
(22.22 \%)\end{array}$ & $\begin{array}{l}0 \\
(0 \%)\end{array}$ \\
\hline Total & $\begin{array}{l}21 \\
(46.67 \%)\end{array}$ & $\begin{array}{l}19 \\
(42.22 \%)\end{array}$ & $\begin{array}{l}19 \\
(42.22 \%)\end{array}$ & $\begin{array}{l}21 \\
(46.67 \%)\end{array}$ & $\begin{array}{l}20 \\
(44.44 \%)\end{array}$ \\
\hline
\end{tabular}

$\mathrm{n}=$ No. of samples examined from each type of parrots.

Irrespective of types of parrots, the higher percentage of different bacteria was isolated from cloacal swabs (77.78\%) followed by feces $(75.56 \%)$. The $68.89 \%$ isolates were recovered from oral swabs (Table 1). This finding could not be compared due to unavailability of specific literatures. However, it is imperative to note that the bacterial load is usually higher in cloaca and feces than oral cavity of healthy birds (Petrak, 1982). 
The sensitivity patterns of different bacteria to various antibiotics were so variable that it was difficult to interpret. Ampicillin and amoxicillin were found to be completely resistant to E. coli and Pasteurella spp.; and furazolidone to Salmonella spp. and Pasteurella spp. (Table 3). On the other hand, the antibiotics of fluoroquinolone group such as ciprofloxacin, norfloxacin and enrofloxacin showed moderate to high sensitivity against almost all the bacterial isolates (Table 3). Of these, ciprofloxacin was found to be consistently highly sensitive to all the bacterial isolates which is consistent with the findings of Brahmbhatt and Anjaria (1991), Morishita et al. (1996) and Mukhopadhyay et al. (1998).

Table 3. Antibiotic sensitivity pattern of the bacteria isolated from caged parrots

\begin{tabular}{|llllllllll|}
\hline Name of bacteria & Sensitivity & \multicolumn{7}{c|}{ Sensitivity (\%) of the bacterial isolates to various antibiotics } \\
\cline { 2 - 8 } & pattern & AMP & AML & CN & CIP & NOR & PEF & FR & ENR \\
\hline Escherichia coli & Resistant & 100 & 100 & 00 & 00 & 00 & 00 & 00 & 00 \\
& Less & 00 & 00 & 40 & 00 & 00 & 20 & 60 & 00 \\
& Moderate & 00 & 00 & 60 & 20 & 20 & 80 & 40 & 20 \\
Salmonella spp. & High & 00 & 00 & 00 & 80 & 80 & 00 & 00 & 80 \\
& Resistant & 00 & 00 & 00 & 00 & 00 & 00 & 100 & 00 \\
& Less & 20 & 00 & 20 & 00 & 00 & 80 & 00 & 10 \\
Pasteurella spp. & Moderate & 80 & 20 & 80 & 20 & 40 & 20 & 00 & 00 \\
& High & 00 & 80 & 00 & 80 & 60 & 00 & 00 & 00 \\
& Resistant & 100 & 100 & 00 & 00 & 00 & 00 & 100 & 00 \\
Less & 00 & 00 & 20 & 00 & 00 & 40 & 00 & 00 \\
Staphylococcus & Moderate & 00 & 00 & 80 & 40 & 40 & 60 & 00 & 20 \\
& High & 00 & 00 & 00 & 60 & 60 & 00 & 00 & 80 \\
& Resistant & 00 & 00 & 00 & 00 & 00 & 00 & 00 & 00 \\
& Less & 00 & 80 & 20 & 00 & 20 & 00 & 20 & 00 \\
Proteus spp. & Moderate & 20 & 20 & 80 & 00 & 80 & 20 & 80 & 00 \\
& High & 80 & 00 & 00 & 100 & 00 & 80 & 00 & 100 \\
& Resistant & 100 & 00 & 00 & 00 & 00 & 00 & 00 & 00 \\
& Less & 00 & 00 & 33.33 & 00 & 00 & 00 & 00 & 00 \\
& Moderate & 00 & 100 & 66.67 & 00 & 00 & 100 & 100 & 00 \\
& High & 00 & 00 & 00 & 100 & 100 & 00 & 00 & 100 \\
\hline
\end{tabular}

$\mathrm{AMP}=$ Ampicillin; $\mathrm{AML}=$ Amoxicillin; $\mathrm{PEF}=$ Pefloxacin $; \mathrm{CN}=$ Gentamycin; $\mathrm{FR}=$ Furazolidone; CIP = Ciprofloxacin; NOR $=$ Norfloxacin and ENR $=$ Enrofloxacin.

Although, primary bacterial infections are not only a common cause of disease in parrots; a better understanding of normal microbial flora may help in interpreting the significance of bacterial isolates in sick birds (Bangert et al., 1988; Lamberski et al., 2003). A knowledge of normal bacterial flora is also important for identifying potential pathogens that can cause disease during times of stress or immune suppression (Petrak, 1982). For example, Pasteurella multocida can cause septicemia and cutaneous lesions in parrots and their relatives (Morishita et al., 1996). Thus, the results of this study may help pet clinicians to interpret microbiological culture and sensitivity results in parrots and other psittacine birds as well.

\section{REFERENCES}

1. Allgayer MC, LimaRosa CAV, Weimer TA, Rodenbusch CR, Pereira RA, Streck AF, Oliveira SD and Canal CW (2008). Molecular diagnosis of Salmonella species in captive psittacine birds. Veterinary Record 162: 816-819.

2. Altman and Robert B (1997). Avian Medicine and Surgery. WB Saunders Co., Philadelphia, USA.

3. Bangert RL, Cho BR, Widders PR, Stauber EH and Ward ACS (1988). A survey of aerobic bacteria and fungi in the feces of healthy psittacine birds. Avian Diseases 32: 46-52.

4. Bauer AW, Kirby WM, Sheris J and Truck M (1966). Antibiotic susceptibility testing by a standardized single disk method. American Journal of Clinical Pathology 145: 225-230.

5. Bowman TA and Jacobson ER (1980). Cloacal flora of clinically normal captive psittacine birds. The Journal of Zoo Animal Medicine 11 (3): 81-85. 


\section{J. Akhter and others}

6. Brahmbhatt MN and Anjaria JM (1991). Isolation of bacteria from market goat meat and their in vitro antibiotic sensitivity pattern. Indian Journal of Animal Science 63: 522-523.

7. Buxton A and Fraser G (1977). Animal Microbiology. Vol. 1. Blackwell Scientific Publications, Oxford, London.

8. CDC (2005). Compendium of Measures to Prevent Disease Associated with Animals in Public Settings. National Association of State Public Health Veterinarians, Inc., MMWR 54 (No. RR-4).

9. Cheesbrough M (1984). Medical Laboratory Manual for Tropical Countries. Vol-II, Microbiology. $1^{\text {st }}$ edn., English Language Book Society, London.

10. Chatterjee C, Nag NC and Roy JP (1990). Studies on coagulase status and biochemical characters of animal strains of staphylococci. Indian Journal of Animal Health 29 (2): 157-161.

11. Cowan ST (1985). Cowan and Steel's Manual for Identification of Medical Bacteria. $2^{\text {nd }}$ edn., Cambridge University Press, Cambridge, London.

12. Deem SL, Noss AJ, Cuellar RL and Karesh WB (2005). Health evaluation of free-ranging and captive blue-fronted Amazon parrots (Amazona aestiva) in the Gran Chaco, Bolivia. Journal of Zoo and Wildlife Medicine 36 (4): 598-605.

13. Doneley RJT (2009). Bacterial and parasitic diseases of parrots. Veterinary Clinics of North America: Exotic Animal Practice 12 (3): 417-432.

14. Flammer K and Drewes LA (1988). Species-related differences in the incidence of Gram-negative bacteria isolated from the cloaca of clinically normal psittacine birds. Avian Diseases 32: 79-83.

15. Fowler ME (1986). Zoo and Wild Animal Medicine. $2^{\text {nd }}$ edn., WB Saunders Co., London.

16. Freeman BA (1985). Burrows Textbook of Microbiology. $22^{\text {nd }}$ edn., WB Saunders Company, Philadelphia, USA.

17. Friend M and Franson JC (1999). Field Manual of Wildlife Diseases : general field procedures and diseases of birds. US Department of the Interior, US Geological Survey, USA.

18. http://www.parrotsanctuary.co.uk/Sanctuary/DerrenBrown.htm

19. http://www.wikipedia.com

20. Kirk JH, Charles A, Holmberg and Jeffrey JS (2002). Prevalence of Salmonella spp. in selected birds captured on California dairies. American Journal of Veterinary Avian Medicine 220 (3): 359-362.

21. Lamberski N, Hull AC, Fish AM, Beckmen K and Morishita TY (2003). A survey of the choanal and cloacal aerobic bacterial flora in free-living and captive Red-Tailed hawks (Buteo jamaicensis) and Cooper's hawks (Accipiter cooperii). Journal of Avian Medicine and Surgery 17 (3): 131-135.

22. Merchant IA and Packer RA (1967). Veterinary Bacteriology and Virology. $7^{\text {th }}$ edn., The Iowa University Press, Ames, Iowa, USA.

23. Morishita TY, Lowenstine LJ, Hirsh DC and Brooks DL (1996). Pasteurella multocida in Psittacines: prevalence, pathology, and characterization of isolates. Avian Diseases 40: 900-907.

24. Mukhopadhyay HK, Puvarajan B and Dorairajan N (1998). Detection of microbial load in fresh mutton and its impact on public health. Indian Journal of Animal Health 37: 81-83.

25. Petrak ML (1982). Diseases of Cage and Aviary Birds. $2^{\text {nd }}$ edn., Lea \& Febiger, Philadelphia, PA

26. Sandra O, Jesus JH and Duarte C (1998). Potential pathogens recovered from the upper respiratory tract of psittacine birds. Department of Morphology and Clinics, Faculty of Veterinary Medicine, Rua Gomes Freire, 1199 Lisboa codex, Portugal.

27. Shimakura S, Kuzuya M, Morikoshi T, Fukushi H, Okuda Y and Hirai K (1985). Salmonella infection in imported pet birds. Research Bulletin of Faculty of Agricultural Gifu University 50: 251-257.

28. Warshawsky (2002). Outbreak of Escherichia coli 0157:H7 related to animal contact at a petting zoo. Canadian Journal of Infectious Diseases 13 (3): 175-181. 